\title{
REPORT: GENEVA VISIT: 4-9 JULY 1999
}

\author{
Prof. Laetitia J King \\ D.Litt. et Phil. \\ Head: Department of Advanced \\ Nursing Sciences, \\ Unisa
}

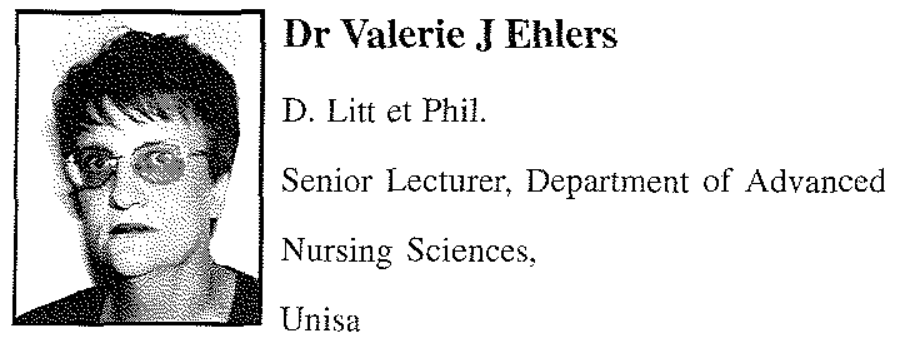

\begin{abstract}
This report provides a brief introduction to Geneva and its many international organisations and aims to share some of the insights gained during discussions held with various key persons at the World Health Organisation (WHO), the International Committee of the Red Cross, and the International Nursing Review (INR), the official journal of the International Nursing Council.
\end{abstract}

Many new insights were obtained which affect the health care professions globally, but specifically the nurses and midwives. One important aspect that came to our attention repeatedly was the necessity for the nurses and midwives to justify the importance and relevance of their roles within multidisciplinary health care teams. Research priorities, especially for postgraduate nurses and midwives, should address multi-disciplinary and interdisciplinary collaborative approaches to community and family health, incorporating community participation.

The visit to the International Committee of the Red Cross centered on the HELP (Health Emergencies in Large Populations) course being offered by this institution. Much information about the working philosophies of the International Nursing Review was obtained during the visit to these offices.

\section{SAMEVATTING}

Hierdie verslag verskaf 'n bondige oorsig oor Geneva se baie internasionale organisasies en poog om sommige gewaarwordinge weer te gee wat verkry is tydens besprekings met sleutelpersone verbonde aan die Wêreld Gesonheids Organisasie (WGO), die Internasionale Komitee van die Rooi Kruis, en die International Nursing Review, die amptelike joernaal van die Internasionale Verpleegstersraad (IVR).

Baie nuwe insigte is verkry wat betrekking het op die globale gesondheidsorg professies, maar spesifiek op die verpleegkundiges en vroedvroue. Een uiters belangrike aspek waarvan ons bewus geraak het, is die herhaalde beklemtoning van die noodsaaklikheid vir vroedvroule en verpleegkundiges om die belangrikheid en ter saaklikheid van hulle rolle binne die multi-dissiplinêre gesondheidsorgspanne te bewys. Navorsingsprioriteite, veral vir nagraadse verpleegkundiges en vroedvroue, behoort multidissiplinêre en inter-dissiplinêre samewerkingsbenaderings tot gemeenskaps-en gesinsgesondheid te beklemtoon, wat gemeenskapsdeelname insltit. 
Die besoek aan die Internasionale Komitee van die Rooi Kruis het rondom die HELP (Health Emergencies in Large Populations) kursus gewentel, wat deur die inrigting aangebied word. Baie inligting aangaande die werkende filosofië̈ van die International Nursing Review was verkry tydens die besoek aan hierdie kantore.

\section{GENERAL INFORMATION ABOUT rica. GENEVA}

Geneva is well known as an international city, housing the headquarters of the International Committee of the Red Cross, the High Commission of the United Nations for Refugees, the second largest center of the United Nations (the largest being in New York) and the headquarters of the World Health Organisation (WHO). This city's tourist bureau boasts that there are 101 places and museums to visits, including the Museum of the International Red Cross and Red Crescent, the Clock and Watch Museum, and the Museum of the Pipe, the Telephone, the Automobile, motorcycle and cycle, and Reformation.

There are also museums commemorating the lives and works of Geneva's well known historical figures such as Rousseau, Voltaire and Calvin (whose theological college later became the current University of Geneva, claiming to contain practically every book printed since the end of the $15^{\text {th }}$ Century in its 32 kilometers of bookshelves in addition to its 1,8 million documents). However, the lasting memories of Geneva are those of a beautiful city surrounded by snow-capped mountains in the middle of summer, the Rhöne river meandering through the city with its peaceful ducks and swans, and the huge lake touching the sky at the horison.

Most people speak French but understand some German. Surprisingly few people seemed to be able to speak English. We met three persons who overheard our Afrikaans conversations and joined in. People from all over the world live and work in Geneva at the many international organisations housed within its borders. During the summer months Geneva's time zone coincides exactly with that of South Af-

On Sunday some sightseeing was done and something learned about the rich and diverse history of this impressive city and about the Canton of Geneva where grapes and grains are cultivated.

\section{PURPOSE OF THE VISIT TO GENEVA}

\section{Main purpose}

The Department of Advanced Nursing Sciences, Unisa became a WHO Collaborating Center (WCC) during 1998. As none of the current staff members of this Department could have attended the WCC Conference held in Korea during 1998, this visit was planned mainly to discuss the current and future activities of this WCC for developing nursing and midwifery in Africa by providing relevant distance education courses.

\section{Subsidiary purposes}

These included:

- To visit the International Red Cross to obtain more information about the HELP (Health Emergencies for Large Populations) programme.

. To visit the headquarters of the International Nursing Review, the official journal of the International Council of Nurses. This was deemed essential prior to the launching of the Africa Journal of Nursing and Midwifery by the Department of Advanced Nursing Sciences, Unisa.

\section{DISCUSSIONS HELD AT THE WORLD HEALTH ORGANIZATION (WHO) HEAD- QUARTERS}

A large number of worthwhile discussions were held 
with a number of diverse key persons representing different aspects of the WHO's activities.

\section{Monday 5 July 1999: Dr Naeema Al-Gasseer, Chief Scientist Nursing}

Dr Al-Gasseer pledged her support for the forthcoming publication of the Africa Journal of Nursing and Midwifery and for the $2^{\text {nd }}$ International Health Care Conference, with the theme Global Multi-Disciplinary Health Care into the $2 I^{\text {st }}$ Century planned for 14-17 August 2000.

Dr Al-Gasseer was informed about the Department's WCC activities in Swaziland and Angola and given a brief overview of the planned future activities and anticipated challenges in meeting the WCC's terms of reference. The importance of developing a multidisciplinary, interdisciplinary collaborative approach to community and family health (with extensive community participation) was discussed at length.

According to Dr Al-Gasseer, the WHO's Director General sees the future of nursing as a profession as depending on how nurses justify and support their role within the multi-disciplinary health care team. Such justifications can be provided through research efforts, which pay special attention to:

competencies required by nurses within the multidisciplinary health care team;

the need to enhance such competencies and the need for nurse educators and leaders to ask whether, and if so, to what extent they strengthen such competencies;

comparisons of competencies as perceived by nurses, doctors and others;

nurses need to state unequivocally what nurses do and why they perform certain actions; nurses need to research how other team members perceive nurses' roles within the multi-disciplinary health care team;

- the difference(s) nurses have made in Africa to date, and the need to substantiate such claims; each country in Africa should research the value, relevance and specific role of nursing; and nursing research should place particular emphasis on WHO priorities such as making pregnancy safer and maternal and child health.

The WHO recognises distance education as the international model for the education of health manpower, for improving qualifications but also for providing continuing education opportunities. The value, relevance and potential of distance education for Africa and further afield was discussed in great depth.

Areas that are of significance to the WHO include:

- policy and strategic planning

- health services and management

human resources

. family and community health action teams.

Partnership, accountability, interrelationships and duties as well as the scope of work of all concerned can be regarded as key words determining the focus of the WHO activities. The importance of collaboration and coordination with others (including Sigma Theta Tau, WCC's, ICN, ICM and the Commonwealth) cannot be overemphasised in ensuring the relevance and importance of nursing as a future profession.

\section{Tuesday 6 July 1999: Dr Olive Shisana, Ex- ecutive Director: Health Systems and Commu- nity Health (CHS)}

Dr Shisana indicated that she had taken note of the Department of Advanced Nursing Sciences, Unisa's role in providing post graduate distance education to nurses and midwives living and working in many African countries. However, Dr Shisana emphasised that continuing education programmes are particularly needed for nurses and midwives. The WHO identified a dire need for upgrading the skills and knowledge of nurse midwives and for training skilled midwifery attendants. Particular emphasis needs to 
be placed on community-based midwifery services, deciding when to refer patients to more specialised services and especially on reducing maternal mortality rates in Africa. Midwives should be encouraged to do research relevant to the needs of their communities and should concentrate on aspects, which could be of direct benefit to their specific countries. An example of a relevant practical research project could be: How should a clinic function in order to be more effective?

\section{Ms Barbara Stilwell, Education and Training}

Ms Stilwell is both a qualified behavioural psychologist and a nurse. Her major function at WHO relates to the identification of ways in which countries could implement normative actions. This includes implementing changes effectively into health care practices. Barriers preventing the effective implementation of change need to be identified and suitable ways sought to overcome them. One example Ms Stilwell mentioned concerned the issue that health care workers should not wear T-shirts bearing HIV/ AIDS messages when visiting patients at home, as the communities will then know in which houses HIV/ AIDS patients live.

Project leaders conducting research with practical implementation implications could be linked with Ms Stilwell's projects to the ultimate benefit of both the students and the countries concerned.

\section{Ms Irene Bertrand, WHO library}

This was indeed a most valuable and informative visit. All documents published by the WHO since 1986 are available in this library. These publications include press releases, documents received by each of the WHO's representative offices in the various countries, all policies adopted about diseases, lifestyle influences on health, and technical reports.

The WHO library was in the process of linking its data sources to those of other web sites. The idea of a Virtual Reference Library was being explored. The WHO Web page can be accessed at http:// www.who.int

Institutions concerned with educating health care personnel can request to be placed on the marketing and mailing lists of the WHO's library.

The WHO library compiles so-called "blue trunk libraries" containing the most important recent publications on relevant aspects in French, Portuguese or English. These trunks can then be transported by any public transportation to specific clinics or health services and moved at regular intervals among any country's health care workers, providing access to reading materials which might have been difficult or impossible to access by any other means. Purchasing one blue box for a country would have cost approximately US $\$ 2000$ (or R12 000.00), but sponsors usually buy these library trunks for specific countries.

\section{Ms Lene Svendsen Grefe, Human Resource Management Project}

During 1992, after meetings held in Washington DC and in Geneva, it became apparent that extremely poor country specific and global information systems existed about the nursing and midwifery manpower situations. The numbers of nurses and midwives globally and in specific countries were largely unknown, as well as their qualifications and places of employment. Field tests were conducted in the Seychelles, Bahrain, Papua New Guinea in order to generate materials for workshops to educate and train people to compile data about nursing and midwifery human. resources in various countries. Sponsorship was obtained from the Kellogg Foundation to initiate and sustain the activities of the Nursing Information Management Systems (NIMS) project. However, in view of the lack of available data in many developing countries, a more comprehensive database was needed and the Human Resources for Health Management Information Systems (HRH MIS) project replaced the NIMS in 1996. Following an initial workshop to 
establish a starting baseline, a two-year project was launched to assess organisational structures in order to set up a comprehensive data base, coordinating with all relevant stakeholders in each country, ensuring that a useful data base for each country's future use would be established. Regular updating and continuous crosschecks need to be instituted to ensure the continued sustainability and relevance of the databases. Potential uses of such databases include:

reviewing a country's staffing norms

identifying educational needs

upgrading specific categories of staff matching needs and resources, such as matching human resource data with epidemiological data.

\section{Wednesday, $7^{\text {th }}$ July 1999: Dr Orvill Adams, Director WHO Department of Health Systems (HSS)}

Prof. King informed Dr Adams about the WCC's terms of reference and activities. Dr Adams, like Dr Al-Gasseer, emphasised that the Director General of the WHO insists on being informed about the relevance of Nursing as a separate issue from general health care. This implies that nurses should be able to indicate what impact nursing has and why this impact is important. (These aspects were reemphasised during follow-up sessions with $\mathrm{Dr} \mathrm{Al}$ Gasseer on 7 July 1999). Dr Adams reiterated that the strength of nursing lies in strengthening the capabilities of nurses at all levels within the multi-disciplinary teams, including:

finding better ways of building nurses' capacities

assessing whether investments are worthwhile utilise distance education strategies to enhance nurses' and midwives' knowledge and skills address the brain drain among nurses in certain countries

enhance the sharing of knowledge among institutions and among different countries

develop global norms and standards for nursing and midwifery.

\section{INTERNATIONAL NURSING REVIEW (INR)}

\section{Wednesday, 7 July 1999: Ms Linda Carrier- Walker, Communications Manager, INR}

The primary purpose of the INR is to coordinate and disseminate nursing research information in collaboration with nursing organisations and other health related organisations, and to provide a global forum for sharing nursing research results. As from 2000 the INR would be published by Blackwell Scientific Publications and relaunched as a fully peer reviewed journal, under editorship of Dr Vivien de Back. Blackwell Scientific Publications handles all actual publication aspects, but the editorial board needs to promote the submission of manuscripts and to review these ensuring that balances are maintained between the official languages of English, French and Spanish; as well as the distribution of articles published according to countries; and that the published articles provide a balance between nursing practice and research. According to the INR's identified nursing research priorities include:

the necessity for the nursing profession to stay grounded within the health field(s) where it operates

clinical health and illness related research challenge to the delivery of effective nursing care quality and cost of nursing care community based nursing care health care reforms issues affecting nurses as part of the health care workforce nursing education issues assessment and monitoring of clients' perceptions of nursing care

testing the effectiveness of nursing interventions assessing the outcomes of nursing care HIV/AIDS as a global health problem infection control women's health mental health health promotion 
genetics.

Contributors who wish to submit original articles for potential publication in the INR can obtain publication details from any issue of INR or can send their requests to:

The Editor

International Nursing Review

3 Place Jean-Marteau

CH 1202

GENEVA

SWITZERLAND

e-mail: icn@uni2a.unige.ch

\section{INTERNATIONAL COMMITTEE OF THE RED CROSS (ICRC)}

\section{Thursday, 8 July 1999: Dr Daniel Koch, Chief Medical Unit, Health Training Program Coor- dinator}

Dr Koch explained that the HELP (Health Emergencies in Large Populations) course by the ICRC is a course for the management of humanitarian assistance targeted at health professionals within the multidisciplinary team. The major part of this course comprises small group work, making a distance education approach difficult. However, discussions were under way with both the Johns Hopkins School of Public Health and with the University of Pretoria to investigate ways in which this course could be adapted to be offered by distance education. An internationally recognised and supported course of this nature could be of immense significance to the health care professionals working in African countries.

\section{WHO: TOBACCO FREE INITIATIVE}

\section{Friday, 9 July, 1999: Dr Derek Yach}

The importance of interdisciplinary collaboration and unity in achieving WHO objectives was stressed. The value of distance education courses for health services personnel needs to be better known globally.
In order to achieve the goals of the WHO's tobacco free initiative, it is essential that:

closer collaboration among different professionals should be established;

- surveys be conducted among health care professionals, including nurses;

- global control should be instituted (such as through a public conventions) on tobacco control;

- health care students should be linked to the WHO website in order to obtain the most recent information possible;

curricula should emphasise the problems of tobacco use and health issues;

- legislation, economic implications, attitudes of the tobacco industry be included in curricula; real change, involving legal and financial involvement, would make health education about the dangers of smoking more effective; and nurses should not only provide general health education about smoking but should indeed be able to promote the cessation of smoking among their clients.

\section{CONCLUSION}

The visits to the WHO, International Red Cross and International Nursing Review headquarters in Geneva left us with an urgent need to inform nurses and midwives about the dire necessity of proving their value and relevance within a multi-disciplinary health care approach. The importance of nurses and midwives in rendering health care services cannot be regarded as being non-negotiable, self-evident facts. The necessity for nursing and midwifery services needs to be researched and the difference nurses and midwives can and do make to the lives of people and communities need to be assessed and publicised globally. The future of the nursing and midwifery professions throughout the world might hinge on the availability of research results proving the value of these services, otherwise the nursing and midwifery professions might become displaced by other groups of health care workers. 


\section{Acknowledgements}

We wish to express our sincere gratitude to Unisa for travel grants, which made these visits financially possible. To each person who made time available to discuss issues with us or to inform us about specific activities a heartfelt "thank you" is extended. We realise that they managed to accommodate us despite extreme pressures of time. 